\title{
Pengaruh kegiatan senam irama terhadap kecerdasan kinestetik pada anak kelompok b tk mustabaqul khoir Palembang
}

\author{
Nanda Renza Farah Hasibuan, Taty Fauzi, Rahmah Novianti \\ Universitas PGRI Palembang \\ Jl. Jend A. Yani Lorong Gotong R No. 9/10, Kota Palembang, Sumatera Selatan \\ E-mail: nandarenza10@gmail.com ${ }^{1}$, taty.fauzy@yahoo.co.id ${ }^{2}$, aliciarahmah@gmail.com ${ }^{3}$
}

\begin{tabular}{|c|c|}
\hline ARTICLE INFO & ABSTRACT \\
\hline $\begin{array}{l}\text { Article history: } \\
\text { Received:27-07-2020 } \\
\text { Revised:10-08-2020 } \\
\text { Accepted: } 16-08-2020 \\
\text { Keywords: } \\
\text { senam irama, kecerdasan } \\
\text { kinestetik, anak }\end{array}$ & $\begin{array}{l}\text { Penelitian ini bertujuan untuk mengetahui adakah pengaruh kegiatan senam } \\
\text { irama terhadap kecerdasan kinestetik pada anak kelompok B TK Mustabaqul } \\
\text { Khoir palembang. Sampel dalam penelitian ini adalah anak kelompok B } 1 \text { dengan } \\
\text { jumlah } 16 \text { anak. Penelitian ini menggunakan jenis penelitian eksperimen desain } \\
\text { Pre-Experimental Designs dengan jenis One-Shot Case Study. Dalam desain ini } \\
\text { terdapat suatu kelompok diberi treatment, dan selanjutnya diobservasi hasilnya. } \\
\text { Berdasarkan perhitungan yang didapat untuk data pretest uji normalitas data } \\
\text { yang diperoleh adalah } 0,71 \text { dan data posttest diperoleh } 0.97 \text { sehingga dapat } \\
\text { dikatakan dari kedua data tersebut terdistribusi normal. Kemudian hasil } \\
\text { perhitungan uji normalitas data untuk } F_{\text {hitung }}<F_{\text {tabel }} \text { atau } 1,34<2,11 \text {, maka } \\
\text { varians-varians dinyatakan normal. Tahap berikutnya dilakukan pengujian } \\
\text { hipotesis dari hasil perhitungan uji-t diperoleh } t_{\text {hitung }}=131.40 \text { jika } \\
\text { dibandingkan dengan } t_{\text {tabel }} 16=94,5 \text { berarti tolak } H_{o} \text { dan diterima } H_{a} \text { maka, } \\
\text { perbandingan data pretest dan data posttest dapat disimpulkan bahwa ada } \\
\text { pengaruh kegiatan senam irama terhadap kecerdasan kinestetik pada anak } \\
\text { kelompok B di TK Mustabaqul Khoir Palembang. }\end{array}$ \\
\hline
\end{tabular}

\begin{abstract}
This study aims to determine whether there is an effect of rhythmic gymnastic activities on kinesthetic intelligence in group B children Mustabaqul Khoir kindergarten in Palembang. The sample in this study were children of group B1 with a total of 16 children. This study uses a type of experimental research design Pre-Experimental Designs with the type of One-Shot Case Study. In this design there is a group given treatment, and then the results are observed Based on the calculation obtained for the pretest data normality test data obtained is 0.71 and posttest data obtained 0.97 so that it can be said of the two data normally distributed. Then the calculation results for normality test data for $F_{-}$(count) $<F_{-}$(table) or $1.34<2.11$, then the variance is declared normal. The next stage is to test the hypothesis from the results of the t-test calculations obtained $t_{-}$ $($ count $)=131.40$ when compared $w i t h t$ table $16=94.5$ means reject $H_{-} o$ and accepted $H \_a$, then the comparison of pretest data and posttest data can be concluded that there is an effect of rhythmic gymnastic activities on kinesthetic intelligence in group B children in TK Mustabaqul Khoir Palembang.
\end{abstract}

\section{PENDAHULUAN}

Pendidikan anak usia dini adalah pemberian upaya untuk menstimulasi pertumbuhan dan perkembangan anak agar dapat tumbuh dan berkembang secara optimal sesuai dengan tahapan usianya dan dapat membentuk karakter anak dari sejak dini. Pendidikan anak usia dini merupakan salah satu bentuk penyelenggaraan pendidikan yang menitikberatkan pada peletakan dasar ke arah pertumbuhan dan perkembangan fisik, kecerdasan, sosial emosional, bahasa, dan komunikasi sesuai dengan keunikan dan tahap-tahap perkembangan yang dilalui oleh anak usia dini. 
Jurnal Pendidikan Anak, Volume 9 (2), Tahun 2020

Nanda Renza Farah Hasibuan, Taty Fauzi, Rahmah Novianti

Terdapat berbagai jenis kecerdasan yang ada pada diri anak dari sejak lahir yang dapat terus menerus dikembangkan salah satunya kecerdasan jamak, kecerdasan jamak adalah berbagai keterampilan dan bakat yang dimiliki anak dengan tingkat yang berbeda-beda yang dapat digunakan untuk menyelesaikan berbagai persoalan dalam pembelajaran dan dapat dikembangkan secara terus menerus. Kecerdasan kinestetik merupakan salah satu dari kecerdasan jamak yang ada dalam diri anak yang berkaitan dengan kecerdasan dalam hal menggabungkan antara fisik dan pikiran sehingga menghasilkan gerakan.

Menurut Taty dan Bayu (2019, p 82), hakikat kecerdasan adalah sebuah kemampuan untuk menjelaskan tingkat kemampuan berpikir seseorang. Sampai saat ini kecerdasan masih digunakan sebagai indikator untuk mengukur kemampuan berpikir, mengetahui, memahami, menganalisis, menentukan, dan menjelaskan tentang sesuatu. Kecerdasan terletak pada otak bagian "cortex (kulit otak)" yang memberikan kemampuan untuk berhitung, berkreasi, berimajinasi, beranalogi, dan melakukan inovasi.

Sedangkan Taty, dkk (2018) menyatakan bahwa kecerdasan terbagi menjadi dua yaitu kecerdasan IQ dan kecerdasan emosional. Kecerdasan IQ merupakan sebuah kemampuan untuk menjelaskan tingkat kemampuan berpikir (otak kiri) seseorang. Sedangkan kecerdasan emosi merupakan salah satu bagian yang paling penting dari manusia, karena melalui emosi individu mampu mengekspresikan perasaannya, selain itu juga pada setiap aspek perkembangan manusia pasti terdapat perkembangan emosi didalamnya.

Selanjutnya Gardner dalam Budiartati (2007, p96) menegaskan bahwa kecerdasan anak tidak hanya ditentukan oleh skor tunggal yang diungkap oleh tes intelegensi. Pada dasarnya, anak memiliki sejumlah kecerdasan (kecerdasan jamak) berupa keterampilan dan kemampuan yang mewakili berbagai cara anak dalam belajar dan berinteraksi dengan diri dan lingkungannya.

Berdasarkan pendapat para ahli diatas, maka dapat disimpulkan bahwa kecerdasan merupakan kemampuan seseorang untuk berpikir, memahami, menganalisis, dan menjelaskan tentang sesuatu dengan berbagai cara melalui belajar dan berinteraksi dengan diri dan lingkungannya.

Darsinah (2012, p 86) mengemukakan bahwa kecerdasan kinestetik adalah kecerdasan dimana saat menggunakannya kita mampu melakukan gerakan-gerakan yang bagus, berlari, menari, membangun sesuatu. Sedangkan menurut Suyadi (2010, p 116) kecerdasan kinestetik adalah kemampuan untuk menggabungkan antara fisik dan pikiran sehingga menghasilkan gerakan yang sempurna. Jika gerak sempurna yang bersumber dari gabungan antara pikiran fisik tersebut terlatih dengan baik, maka apapun yang dikerjakan orang tersebut akan berhasil dengan baik. Adapun, Musfiroh (2005, p 63) kecerdasan kinestetik merupakan kecerdasan gerak kinestetik berkaitan dengan kemampuan menggunakan gerak seluruh tubuh untuk mengekspresikan ide atau perasaannya serta keterampilan mempergunakan tangan untuk menciptakan atau mengubah sesuatu. Selanjutnya, Faruq (2007, p 43) kecerdasan kinestetik adalah kemampuan menyelaraskan pikiran dengan badan sehingga apa yang dikatakan oleh pikiran akan tertuang dalam bentuk gerakan.

Berdasarkan pendapat para ahli diatas, maka dapat disimpulkan bahwa Kecerdasan kinestetik adalah kemampuan menggunakan gerak seluruh tubuh dan keterampilan menggunakan tangan untuk menciptakan sesuatu serta kemampuan menyelaraskan pikiran dengan badan sehingga apa yang dikatakan oleh pikian akan tertuang dalam bentuk gerakan.

Pada masa usia dini, stimulasi yang paling baik diberikan untuk meningkatkan kecerdasan kinestetik kepada anak salah satunya yaitu melalui senam irama karena anak-anak sangat suka bergerak apalagi diikuti dengan irama musik dan lagu yang semangat dan riang gembira akan dapat mengekspresikan dirinya.

Syarifudin (2014, p 116) menyatakan bahwa Senam irama adalah gerakan senam yang dilakukan dengan irama atau musik atau aktivitas gerak yang dilakukan secara berirama. Sedangkan 
Utomo (2008, p 90) menyatakan bahwa senam irama adalah gerakan senam yang dilakukan dengan irama musik atau latihan bebas yang dilakukan secara berirama. Disini senam irama dapat dilakukan dengan gerakan senam yang sudah ditentukan atau gerakan bebas sesuai dengan keinginan masingmasing individu. Adapun Sutisna (2004, p 68) menjelaskan bahwa senam irama adalah senam yang diiringi dengan irama dan gerakannya harus tetap mengikuti irama. Senam Irama merupakan perpaduan antara gerakan olahraga dan seni tari. Senam Irama mengutamakan gerakan yang indah dan dapat dilakukan dengan cara berjalan atau berlari. Selanjutnya Ahmad dalam Zulfahmi (2016, p 40) menyatakan bahwa senam irama juga dapat diartikan sebagai salah satu senam yang dilakukan dengan mengikuti irama musik atau nyanyian yang kemudian terbentuk suatu koordinasi gerak antara gerakan anggota badan dengan alunan irama.

Berdasarkan pendapat para ahli di atas, maka dapat disimpulkan bahwa senam irama adalah suatu perpaduan berbagai bentuk gerakan dengan mengikuti irama musik. Gerakan yang dilakukan harus sesuai dan selaras dengan irama yang mengiringinya agar gerakan yang dilakukan terlihat serasi kemudian terbentuk suatu koordinasi gerak antara gerakan anggota badan dengan alunan irama

Melihat dari hasil pengamatan yang telah dilakukan oleh peneliti di TK Mustabaqul Khoir, terutama dalam hal kecerdasan kinestetik pada anak anak kelompok B peneliti melihat belum tercapainya kecerdasan kinestetikanak dengan baik. Mulanya dalam melakukan gerakan anak masih terlihat malu karena dilihat teman sekelasnya, anak masih belum terlatih, terlihat kaku dan belum dapat mengkoordinasikan gerakan mata, kaki dan tangan dengan baik, anak masih kesulitan dalam menyesuaikan irama dengan gerakan seperti dalam melakukan gerakan langkah kaki ke kiri dan kekanan, ada juga yang masih belum bisa bergerak mengikuti gerakan senam.

Selanjutnya, berdasarkan pertimbangan-pertimbangan serta melihat permasalahan yang ada pada anak kelompok B TK Mustabaqul Khoir Palembang, maka peneliti tertarik untuk melakukan penelitian dengan judul "Pengaruh Kegiatan Senam Irama Terhadap Kecerdasan Kinestetik Pada Anak Kelompok B TK Mustabaqul Khoir Palembang.

\section{METODE}

Penelitian ini menggunakan jenis penelitian eksperimen dengan metode penelitian kuantitatif. Penelitian ini termasuk dalam desain penelitian Pre-Experimental Designs dengan jenis One-Shot Case Study (Sugiyono, 2009). Dalam desain ini terdapat suatu kelompok diberi treatment, dan selanjutnya diobservasi hasilnya. Penelitian ini dilakukan di TK Mustabaqul Khoir yang beralamat di Jl. Ir. Sutami Kec. Kalidoni Palembang dengan jumlah 16 anak yang terdiri dari 9 anak laki-laki dan 7 anak perempuan. Teknik pengumpulan data yang digunakan dalam penelitian ini adalah observasi dan dokumentasi. Adapun teknik analisis data pada penelitian ini digunakan untuk membuktikan hipotesis penelitian, yaitu kegiatan senam irama berpengaruh terhadap kecerdasan kinestetik pada anak kelompok B di TK Mustabaqul Khoir Palembang. Teknik analisis data yang digunakan pada penelitian ini uji normalitas, uji homogenitas dan uji hipotesis. Untuk mengetahui kebenaran hipotesis pada penelitian ini, maka kriteria pengujian hipotesis dalam penelitian ini adalah jika $t_{\text {hitung }}>t_{\text {tabel }}$ berarti Ho ditolak, Ha diterima jika $t_{\text {hitung }}<t_{\text {tabel }}$ berarti Ho diterima, Ha ditolak.

\section{HASIL DAN PEMBAHASAN}

\section{Hasil}

Berdasarkan perhitungan yang didapat untuk data pretest uji normalitas data yang diperoleh adalah 0,71 dan data posttest diperoleh 0.97 sehingga dapat dikatakan dari kedua data tersebut terdistribusi normal. Kemudian hasil perhitungan uji normalitas data untuk $F_{\text {hitung }}<F_{\text {tabel }}$ atau 1,34 $<2,11$, maka varians-varians dinyatakan normal. Selanjutnya setelah pengujian normalitas data dan homogenitas dilakukan dan dinyatakan data tersebut terdistribusi normal dan varians dalam penelitian 
tersebut homogen, maka tahap berikutnya dilakukan pengujian hipotesis dari hasil perhitungan uji-t diperoleh $t_{\text {hitung }}=131.40$ jika dibandingkan dengan $t_{\text {tabel }} 16=94,5$ berarti tolak $H_{o}$ dan diterima $H_{a}$ maka, perbandingan data pretest dan data posttest dapat disimpulkan bahwa ada pengaruh kegiatan senam irama terhadap kecerdasan kinestetik dalam proses belajar mengajar terjadi peningkatan.

\section{Pembahasan}

Dan hasil penelitian teori kegiatan senam irama terhadap kecerdasan kinestetik anak yang sesuai dengan teori menurut Syarifudin (2014, p 116) Senam irama adalah gerakan senam yang dilakukan dengan irama atau musik atau aktivitas gerak yang dilakukan secara berirama. Jadi dalam kegiatan senam irama dapat mengembangkan kecerdasan kinestetik. Sehubungan dengan menurut Utomo (2008, p 90) Senam irama adalah gerakan senam yang dilakukan dengan irama musik atau latihan bebas yang dilakukan secara berirama. Disini senam irama dapat dilakukan dengan gerakan senam yang sudah ditentukan atau gerakan bebas sesuai dengan keinginan masing-masing individu.

Dan hasil penelitian ini menunjukan pada TK Mustabaqul Khoir Ada Pengaruh kegiatan senam irama terhadap kecerdasan kinestetik anak. Melalui kegiatan senam irama dikarenakan kegiatan ini sangat menyenangkan dan tidak membosankan bagi anak.

Dengan penelitian dari Arni Yuliansih (2015) yang berjudul Pengaruh Senam Irama Terhadap Kemampuan Motorik Anak usia 4 Tahun, adapun hasil penelitiannya tentang kemampuan motorik kasar anak pada kelompok perlakuan menggunakan uji Wilcoxon yaitu, motorik kasar nilai $\mathrm{p}=0,14$, motorik halus nilai $\mathrm{p}=0,046$, motorik kasar dan halus nilai $\mathrm{p}=0,025$. Hal ini menunjukkan bahwa Ha diterima dan Ho ditolak. Sedangkan pada kelompok kontrol hasil analisa data pada motorik kasar, motorik halus dan motorik kasar dan halus dengan nilai $\mathrm{p}=1.000$. Hal ini menunjukkan bahwa Ha ditolak dan Ho diterima karena pada kelompok kontrol tidak diberikan perlakuan apapun. Jadi dapat disimpulkan bahwa ada pengaruh senam irama terhadap kemampuan motorik anak usia 5 tahun.

Adapun penelitian dari Ratna Prihantini (2016) yang berjudul Pengaruh Kegiatan Senam Terhadap Kecerdasan Kinestetik Anak Kelompok A di TK Pertiwi II Metuk, adapun hasil penelitiannya adalah kegiatan senam irama berpengaruh terhadap kecerdasan kinestetik. Kegiatan senam irama lebih menekankan pada anak untuk berpartisipasi menggerakkan seluruh tubuhnya. Sehingga anak yang akan aktif mengikuti gerak-gerakan senam irama dengan iringan irama senam. Kecerdasan kinestetik dapat dipengaruhi faktor pembelajaran dari pendidik. Semakin banyak kegiatan yang bervariatif dan inovatif diberikan oleh pendidik, semakin banyak pula peluang kecerdasan kinestetik anak yang terasah sehingga dapat berkembang dengan baik, sehingga anak tidak bosan atau malas untuk mengikuti kegiatan yang diberikan oleh pendidik.

Selanjutnya penelitian dari Windy Agustin Ningsih (2019) yang berjudul Pengaruh Gerak dan Lagu Terhadap Kecerdasan Kinestetik Anak Kelompok B TK Tunas Muda Kecamatan Bahar Selatan, adapun hasil penelitiannya terdapat pengaruh gerak dan lagu terhadap kecerdasan kinestetik kelompok $B$ di TK Tunas Muda Kecamatan Bahar Selatan, berdasarkan hasil perhitungan $t_{\text {hitung }}>t_{\text {tabel }}$ yaitu 6.4465 $>$ 1.6772. $t_{\text {tabel }}$ didapat dari $n 1=+n 2-2=48$ yang dalam distribusi $t_{\text {tabel }}$ didapat nilai 1,6772 . Data tersebut menunjukan pengaruh yang signifikan gerak dan lagu terhadap kecerdasan kinestetik anak kelompok B di TK Tunas Muda Kecamatan Bahar Selatan. Karena $t_{\text {hitung }}>t_{\text {tabel }}$ maka Ha diterima dan Ho ditolak pada taraf kepercayaan 95\%, sehingga dapat disimpulkan bahwa terdapat pengaruh gerak dan lagu terhadap kecerdasan kinestetik kelompok B di TK Tunas Muda Kecamatan Bahar Selatan.

Berdasarkan uraian di atas dapat disimpulkan bahwa telah terbukti kebenarannya bahwa kegiatan senam yang lebih difokuskan pada senam irama memiliki pengaruh yang signifikan terhadap kecerdasan kinestetik pada anak kelompok B di TK Mustabaqul Khoir Palembang. 
Jurnal Pendidikan Anak, Volume 9 (2), Tahun 2020

Nanda Renza Farah Hasibuan, Taty Fauzi, Rahmah Novianti

\section{SIMPULAN}

Berdasarkan hasil penelitian melalui data dan pembahasan, bahwa terdapat pengaruh antara kegiatan senam irama terhadap kecerdasan kinestetik anak pada kelompok B di TK Mustabaqul Khoir Palembang dapat disimpulkan bahwa rata-rata kegiatan senam irama pada data pretest sebesar 61.06 kriteria sesuai dan data posttest 84.93 sangat sesuai. Hasil hipotesis menunjukan ada pengaruh kegiatan senam irama terhadap kecerdasan kinestetik pada anak kelompok B di TK Mustabaqul Khoir Palembang dengan hasil uji-t diperoleh $t_{\text {hitung }}=131.40 \quad t_{\text {tabel }} 16=94,5$ berarti $H_{o}$ ditolak dan $H_{a}$ diterima sangat sesuai.

Sehubungan dengan hasil penelitian yang didapat mengenai pengaruh kegiatan senam irama terhadap kecerdasan kinestetik anak pada kelompok B di TK Mustabaqul Khoir Palembang peneliti menyarankan untuk guru, agar dapat menambah bahan pembelajaran salah satunya dengan menggunakan kegiatan senam irama untuk mengembangkan kecerdasan kinestetik anak di TK Mustabaqul Khoir Palembang. Untuk anak, agar dapat lebih fokus dalam mengikuti kegiatan belajar sehingga tujuan pembelajaran dapat tercapai dengan baik. Untuk mahasiswa atau peneliti diharapkan dapat mengembangkan hasil penelitian dan dapat meningkatkan mutu pembelajaran dengan mengetahui permasalahan-permasalahan di sekolah untuk mencapai pendidikan yang bekualitas.

\section{UCAPAN TERIMAKASIH}

Peneliti mengucapkan terima kasih kepada berbagai pihak yaitu para dosen di jurusan PAUD Universitas PGRI Palembang, pihak sekolah tempat penelitian, para subjek penelitian, dan pihak lainnya yang telah memberikan dukungan dan dorongan sampai terselesaikannya penelitian ini.

\section{DAFTAR PUSTAKA}

Darsinah. (2011). Perkembangan kognitif. PSKGJ-FKIP Universitas Muhammadiyah Surakarta: Qinant.

Budiartati, E. (2007). Pembelajaran melalui bermain berbasis kecerdasan jamak pada anak usia dini. Tersedia di https://journal.unnes.ac.id/nju/index.php/LIK/article/download/531/488. Diakses Tanggal 18 Juli 2020 pukul 08.30

Faruq, M. M. (2007). 100 permainan kecerdasan kinestetik. Jakarta: Grasindo.

Musfiroh, T. (2005). Bermain sambil belajar dan mengasah kecerdasan. Jakarta: Departemen Pendidikan Nasional Direktorat Jenderal Pendidikan Tinggi.

Ningsih, W. A. (2019). pengaruh gerak dan lagu terhadap kecerdasan kinestetik anak kelompok B di TK Tunas Muda Kecamatan Bahar Selatan. Universitas Jambi. Tersedia di https://core.ac.uk/download/pdf/148601174.pdf\&sa. Diakses tanggal 22 Juli 2020 pukul 08.10.

Prihantini, R. (2016). Pengaruh kegiatan senam terhadap kecerdasan kinestetik anak kelompok A di TK Pertiwi II Metuk. Skripsi.(Surakarta: Universitas Muhammadiyah Surakarta). Tersedia di https://eprints.ums.ac.id/42654/2. Diakses Tanggal 21 Juli 2020 pukul 20.05.

Syarifudin dan Wiradiharja, S. (2014). Pendidikan jasmani olahraga dan kesehatan. Jakarta: Kemendikbud. 
Jurnal Pendidikan Anak, Volume 9 (2), Tahun 2020

Nanda Renza Farah Hasibuan, Taty Fauzi, Rahmah Novianti

Sugiyono. (2009). Metode penelitian kuantitatif kualitatif dan R\&D. Bandung: Alfabeta.

Sutisna, dkk. (2004). Pendidikan jasmani media berolahraga dan berprestasi. Jakarta: Yudistira.

Suyadi. (2010). Psikologi belajar PAUD. Yogyakarta: Pedagogia.

Taty, ., \& Bayu, I.U. (2019). Psikologi Peprkembangan. Tangerang: Tira Smart.

Taty, F, \& Syska, P.S. (2018). Kemampuan mengendalikan emosi pada siswa dan implikasinya terhadap bimbingan dan konseling. Universitas PGRI Palembang. Tersedia di https://jurnal.univpgripalembang.ac.id/index.php/prosiding/article/view/1497. Diakses Tanggal 11 Juli 2020 pukul 09.00 .

Utomo, S. (2008). Pendidikan jasmani olahraga dan kesehatan. Jakarta: Bumi Aksara.

Zulfahmi, M.N. (2016). Pengaruh senam irama terhadap keterampilan gerak dasar anak usia 5-6 tahun. Universitas Negeri Semarang. Tersedia di https://lib.unnes.ac.id/28934/1/1601411036. Diakses pada tanggal 18 Juli 2020 pukul 08.52 